\title{
SUSTAINABLE SUPPLY CHAIN IN THE DEVELOPMENT OF RENEWABLE ENERGY BASE ON BAMBOO FOREST BIOMASS (DEVELOPMENT SOLUTION FOR UNDERDEVELOPED AREAS IN INDONESIA)
}

\author{
Johannes W. Wahono ${ }^{1}$, Bambang Dwi Wijanarko ${ }^{2}$, Ujang Sumarwan ${ }^{3}$, Bustanul Arifin $^{4}$, Herry Purnomo

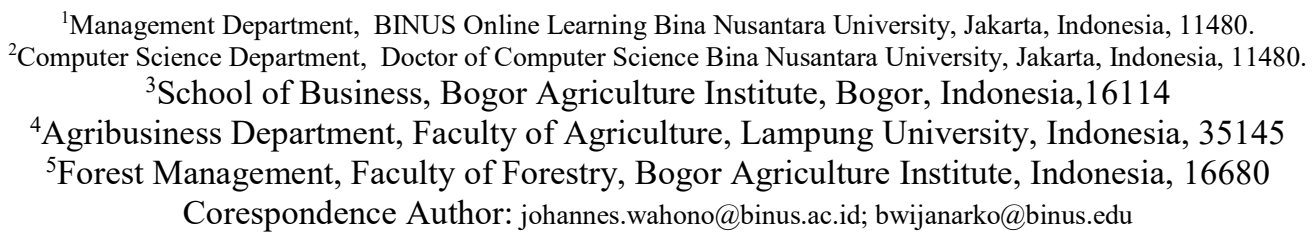

Abstract

The main objective of this study is to examine, with a comprehensive systematic approach and framework for the analysis of the economic feasibility and methodology of the application of bamboo forest biomass technology as renewable energy for the environment and sustainable regional development.This study was conducted in the subdistricts of South Siberut and Central Siberut, Mentawai Islands district, West Sumatra, as an example for the economic development of underdeveloped areas that have bamboo forests suitable for renewable energy materials.The result is a sustainanle supply chain of renewable energy development that addresses technical complexity, economic scale, capital costs, and renewable energy funding challenges, for small to medium-sized projects and not connected to off-grid networks.

Keywords : business model, supply chain, renewable bamboo biomass energy

\section{Introduction}

Indonesia is an archipelago consisting of $\pm 17,508$ large and small islands with a coastline of $\pm 810,000 \mathrm{~km}$ and an area of 3.1 million $\mathrm{km}^{2}$. With more than 65,000 villages spread over thousands of islands, fewer than half have enjoyed state power lines, while others are far from expectations, with most of them still using kerosene/ petromak lamps for lighting. To obtain information from Radio they use batteries, while for television sometimes they use batteries and generators.

The increasing use of electricity as well as the increasingly integrated digital technology in all sectors of life leads to an increased risk of dependence on the entire economy to the availability and quality of power supplies. This risk can be overcome by shifting the distribution of power supply sources with centralized control, power supply, and good power management.

Indonesia's electrification ratio currently reaches 84.35 percent, province with a ratio below 50 percent is Papua province (36.41 percent), and provinces with ratios below 70 percent includes NTT (54.77 percent), Southeast Sulawesi 62.51 percent), NTB (64.43 percent), Central Kalimantan (66.21 percent), West Sulawesi (67.6 percent), Gorontalo (67.81 percent) and Riau Islands (69.66 percent).

The condition of electricity infrastructure in Indonesia is very concerning. The generating capacity is $35.33 \mathrm{GW}$ (gigawatt) to meet the needs of 237 million people. The capacity is far below the production capability of Singapore and Malaysia. The capacity of the plant in Singapore is capable of producing electricity of $10.49 \mathrm{GW}$ to meet the needs of 5.3 million people. Malaysia's generating capacity is $28.4 \mathrm{GW}$ for 29 million residents.

Efforts are needed to harness the potential of renewable energy. (Potential renewable energy such as hydro power, geothermal, wind, solar, ocean, and biomass is sufficient but scattered). 
A. Research Questions

The issues to be studied are as follows:

1. What factors will affect the uncertainty in the supply chain system of renewable energy development?

2. How is the development of feedstock, especially in sustainable supply chain system and how is the value chain obtained from the development of this non-timber forest plantation?

3. How is the biomass-based renewable energy development model for bamboo for rural areas?

B. Research Objectives

This study aims to:

1. Identify what factors will influence the supply chain system of renewable energy development based on bamboo forest biomass.

2. Design a feedstock system of bamboo biomass with sustainable bamboo forest empowerment.

3. Design a sustainable supply chain business model on the development of renewable bamboo biomass energy

C. Research Benefits

1. Contribute to investors and business actors in developing renewable energy based on bamboo forest biomass for electrification in disadvantaged areas.

2. Provide a systemic approach in the supply chain of sustainable biomass bamboo forest.

3. Provide models of development for underdeveloped areas with green energy design that can be applied in all regions in Indonesia.

D. Novelty

The lack of a thorough evaluation of renewable energy technologies as an option for the development of underdeveloped regions in previous studies, requires research that underscores the need to develop an analytical framework with a comprehensive systemic approach and methodology that supports the sustainability criteria.

This study aims to meet this need, by developing a comprehensive model through multidimensional analysis design. This research intends to take steps towards establishing an effective sustainable supply chain model to materialize the concept of sustainable development with renewable energy options for the growth of underdeveloped regions in Indonesia.

\section{Literature Review}

A. Supply Chain Structure

The components of supply chain science that serve as the basis of theory in this study refers to the logistic Body of Knowledge and supply chain management formulated by Ronald $\mathrm{H}$. Ballou in his publication article "The Evolution and Future of Logistics and Supply Chain Management" as presented in Figure 2.1 (Ballou, 2007).

Supply chain management of agriculture and argo-industry also have a similar structure, namely the main components in the form of argological, strategic planning, finance, 
and marketing as well as the importance of the implementation of information and communication technology (Marimin, 2017). The structure of the agro-industry supply chain in general and bioenergy in particular refers to the process chain, added value, risk, material flow and information from upstream to downstream. There are three stages in the flow of materials: raw materials of the bioenergy are distributed to biomass renewable power plants forming a physical supply system, the plant will the process biomass into electrical energy before they are distributed through the power grid (PLN) to consumers, forming a physical distribution system. This distribution flow is aided by related information and financial flows.

\section{B. Supply Chain Institutions}

The success of the supply chain institution depends on the extent to which the parties involved are able to establish the key success factors that underlie any activity within the institution. The key to success is identified through a detailed search of each activity in the supply chain. The key to success is strengthening trust, coordination and cooperation, easy access to finance and government support, and community support (Marimin, Darmawan, Machfud, Islam Fajar Putra, \& Wiguna, 2014).

\section{Analyze and Balancing the Added Value}

Added Value is a value expansion that occurs because of input applied to a commodity. This input causes the added value of a commodity to improve the quality and price of the commodity. The flow of added value of agroindustry commodity occurs in each supply chain from upstream to downstream starting from farmers and ending in the final consumer. The added value of each member of the supply chain differs depending on input and treatment by each supply chain (Taylor, 2005). Hidayat and Marimin (2014) developed a value-added equilibration model in the palm oil supply chain taking into account the risks, investments, and length of production processes schematically, expressed as follows:

\section{Distribution of Added Value $=\mathrm{f}$ (investment, risk, process time)}

This model is effective enough to distribute added value to every supply chain actor. The mechanism is that the actor who has a profit on top of the weight of the risk should decrease the value of his profits, while the actor who gets the profit under the weight of the risk should increase their profit so that the risk score and profit will be balanced at a certain point.

\section{Equal Risk Analysis and Balancing}

Supply chain risk analysis is part of supply chain management that must be done to avoid or reduce the occurrence of business failure in uncertain conditions. Supply chain category is divided into 17 types, namely; (Schoenherr, Rao Tummala, \& Harrison, 2008)

1. the risk of complaint of standardization

2. product quality risk

3. supply risk

4. warehousing risk

5. the risk of sending accuracy

6. risk of delivery budget accuracy

7. risk of order fulfillment

8. risk of partner's mistake

9. supplier risk

10. supplier management risk

11. distance risk

12. transportation risk 
13. engineering and innovation risk

14. risk of production costs

15. risk of competition costs

16. disaster risk

17. foreign product risk

Suhardjito and Marimin developed a model of supply chain risk balancing with stakeholder dialogue approach and fuzzy-nonlinear regression. Model output is the price agreement of the product/commodity at each supply chain level. Pricing at each level of the supply chain is done through stakeholder dialogue between interested parties so as to obtain consensus (agreement) of product commodity prices. With the price agreement there will be a risk utility balance between the farmers and other parties besides the farmers (Suharjito \& Marimin, 2012).

\section{E. Management of Sustainable Green Supply Chain}

The key challenge facing companies of all sizes and industries is to be more accountable to the environment and society. It is widely acknowledged that they must address sustainability issues in their supply chain operations and management. (Singh \& Trivedi, 2016). To adopt and develop sustainability broadly, there should be increased attention to supply chains that focus on the triple bottom line approach ie; environmental, economic, and social. (Ashby, Leat, \& Hudson-Smith, 2012).

\section{F. The Supply Chain of Bioenergy and Stakeholders}

The decline in fossil fuel stocks resulted in the need to seek more intensively on renewable energy options. Following the concept of sustainable development as defined by the Brundtland Commission, the energy system must be ecologically, socially and economically sustainable, so that the present generation can meet its energy needs without diminishing the ability of future generations to meet theirs as well as other needs (Brundtland, 1987).

Thus bioenergy can play an important role, as it helps preserve non-renewable resources, increase energy security, reduce greenhouse gases, and encourage regional development, if set in favorable conditions (Gold, 2011).

Carefully designed and operated bioenergy projects have promising potential to contribute to sustainable development by mitigating climate change and strengthening their adaptive capabilities through decentralized bioenergy production especially in developing countries. This decentralized bioenergy project will have a beneficial effect on rural agroecosystems, leading to increased livelihood opportunities and poverty alleviation, while involving NGOs and residents in the early stages of bioenergy projects through transparent, two-way communication will increase community acceptance (Gold, 2011 ).

To make the supply chain more socially responsible, companies need to apply supplier assessment tools and collaborative practices with suppliers (Gimenez \& Tachizawa, 2012).

On the other hand, there is a need for social and environmental considerations in the supply chain by analyzing the biomass feedstock sources of biofuel production from the poor to reduce environmental and social impacts. (Hall \& Matos, 2010).

\section{G. Previous Related Research}

1. Stochastic Optimization Model: An analysis of the uncertainty of renewable energy investments with the help of stochastic optimization models has been widely used. Reinelt and Keith use a stochastic dynamic model to analyze technological options and investment optimization taking into account $\mathrm{CO}_{2}$ emissions levels and uncertain natural gas prices (Keith \& Reinelt, 2009). 
2. Multi Stage Stochastic Optimization Design Model: Previous research on the bioenergy supply chain can be summarized into two categories: deterministic design and stochastic design. In a supply chain deterministic design it assumes that all parameters are known and fixed, while those assumptions do not apply to stochastic design to account for the uncertainty in decision making.

3. Biomass Value Chain Optimization Model: Samsatli develops the Biomass Value Chain Model (BVCM) which is a comprehensive and flexible optimization toolkit that models a large number of bioenergy system pathways. This developed model describes the economic and environmental impacts associated with the end-to-end elements of the path: crop production, conversion technology, transportation, storage, local purchases, sales and disposal of resources, as well as $\mathrm{CO}_{2}$ absorption by Carbon Capture System CCS) and forestry.

4. Multiple Criteria Decision Making Model: Risk and uncertainty in decision making is a problem for green supply chain managers. This is especially true in developing countries for renewable energy. Various business models and theoretical framework have been developed to deal with risk factors and uncertainties in this area. Some that have been investigated involve fuzzy decision making where these factors are assigned various values that are classified and arranged to determine which ones are most significant. Two common multi-criteria fuzzy decision frameworks for Green Supply Chain Management (GSCM) practice are Fuzzy Analytical Hierarchy Process (FAHP) and Fuzzy Technique for Order of Preferences by Similarity to Ideal Solution (FTOPSIS).

\section{H. Framework for Green Innovation Business Model}

Initial efforts to pursue eco-innovation as a response from corporate practices to sustainability and green growth particularly manifests at the product level. But some companies have expanded this trend by redesigning their production, process or distribution channel. Even leading firms to take further steps to organizational levels and use them to create value propositions, or even to restructure their business models (Bisgaard et al., 2012)

\section{Methodology}

The study was conducted in the subdistricts of South Siberut and Central Siberut, Mentawai Islands district, West Sumatra, as an example for the economic development of underdeveloped areas that have bamboo forests suitable for renewable energy materials.
A. Research Approach
B. The Research Framework
C. Flow Chart of Research
D. Research Stages
E. Types of Research
F. Data Collection and Data Analysis Methods
G. Data Processing Method

\section{Result And Discussion}

A. Sustainability Analysis

Sustainability of bamboo raw materials will be obtained by:

1. Securing the availability of bamboo as a biomass feedstock throughout the year. A harvest rotation schedule should be carried out and ensure that every household has the same opportunity to supply biomass to a power plant. 
2. Issuing a local regulation that every household will be allocated 0.5-1 Ha of land for new bamboo plantations dedicated to supplying power plants. This regulation needs to be adopted as part of Spatial Planning in Mentawai Islands District.

3. Distribute high quality bamboo seeds to local villagers. These seeds will be supplied by the nurseries and greenhouses in consultation with an experienced bamboo nursery company in this case BNV which is the only company in the world capable of producing tropical bamboo seedlings from tissue culture.

4. Following best practices of bamboo planting for medium and large scale plantations developed by the International Network for Bamboo and Ratan (INBAR).

5. Identify the availability of remaining bamboo and forest before bamboo can be harvested from new plantations.

B. Sustainability of Bamboo Biomass Renewable Energy Supply Chain

The sustainability of bamboo biomass supply chain is analyzed based on 3 dimensions namely economic, social, and environmental dimension. This research is done by soft system methodology (SSM) through seven stages:

1. Identify the problem at hand.

2. Express the problem in rich picture

3. Developing definitions based on the activities of the system developed.

4. Design a conceptual model based on the basic definition of the system.

5. Compare conceptual models with said problems.

6. Discuss of necessary changes

7. Conduct orrective action as a solution.

C. Analysis of Model Development Structures

The structure of the system elements to determine the sustainable supply chain business model for the development of renewable energy of bamboo biomass is done using Interpretive Structural Modeling (ISM) technique. Based on the expert opinion, there are six elements that need to be studied in order to determine the sustainability of the supply chain business model on the development of bamboo biomass as renewable energy, which are:

1. Program objectives element

2. Program needs element

3. Community sector element

4. The main constraint element

5. Possible changes element

6. Related institutions elemet 
D. Supply Chain Institutions and Strategies Sustained

\section{VALUE CHAIN : ENERGY NEEDS FOR RURAL CONSUMERS}

\section{Community \\ Bamboo Forest \\ - Land preparation \\ - Planting \\ - Care \\ - Harvest}

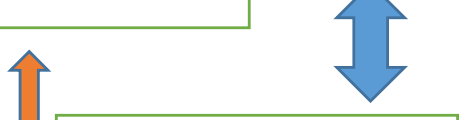

Farmers Cooperative

- Cut bamboo into chips

- Drying bamboo chips

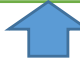

Bamboo Nursery \& Green House

- Prepare superior quality bamboo shoots ready for planting - Supervision \& quality control of bamboo biomass forestry
Biomass Power Plant

- Boiler dry chips

- Gasification process

- Generate Electricity

\section{PLN}

\section{Distribute}

electricity

to

customers
Rural

electricity

customers

SUPPLY CHAIN : ENERGY SUPPLY SECURITY

As a result of library research and FGD as well as discussion of experts, the actors of supply chain for bamboo raw materials and the distribution of electrical energy are as follows:

1. Bamboo farmers

2. Cooperative Enterprises of Farmers

3. Biomass Power Plant (PLTBm)

4. State Electricity Company (PLN)

5. Rural Electricity Consumer

6. Nursery \& Green House of Bamboo Plantation 
E. PPP-BOOM Business Model on PLTBm Bamboo Development

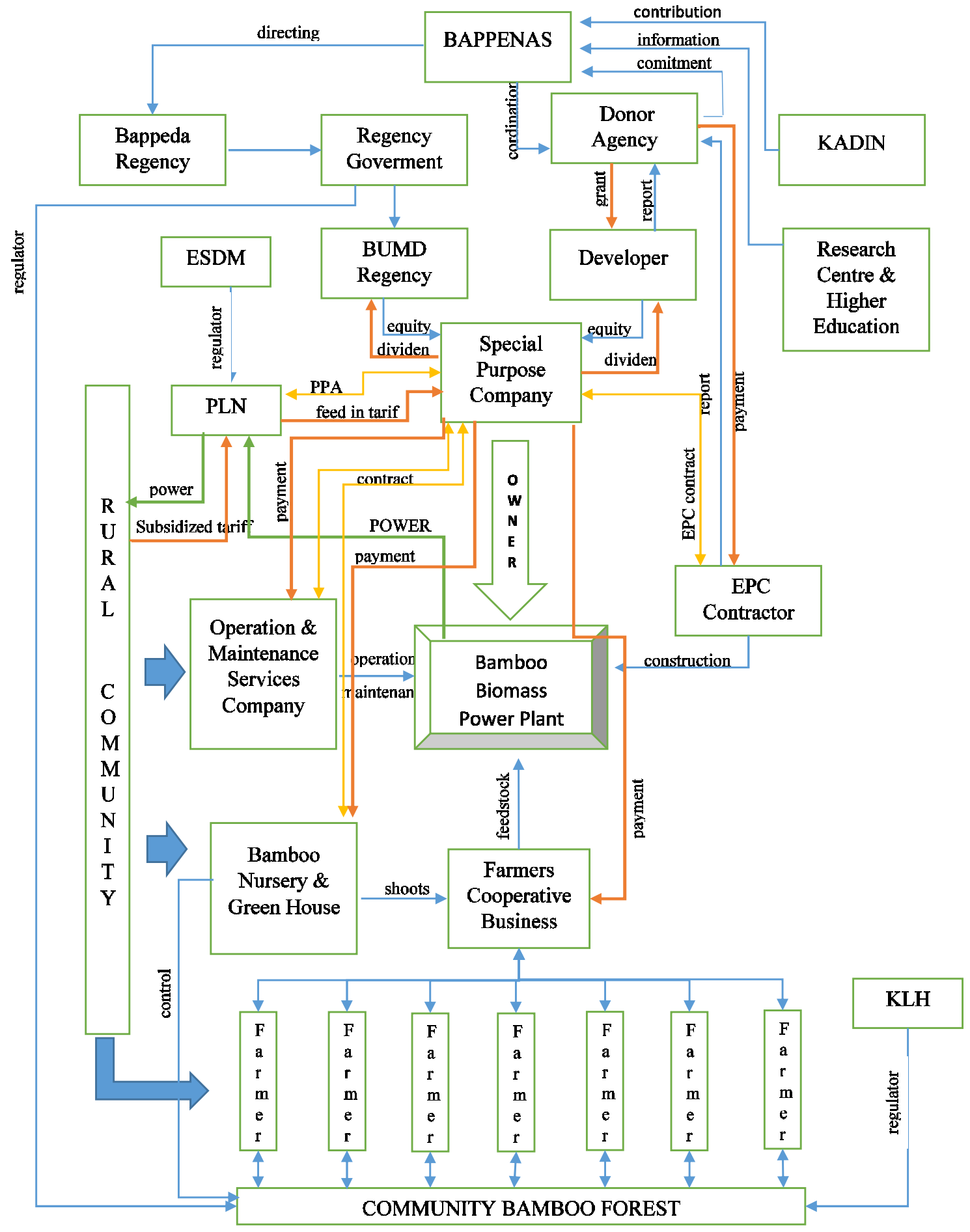




\section{Conclusion and Suggestion}

A. Conclusion

1. The objective of this research is to provide a business model of developing bamboo biomass power plant (PLTBm) with isolated grid on small island communities through assessment of logistical availability, proving value chain and expressing its shortcomings in a pilot project before adapting it as a national program.

2. Based on SAST analysis method on three dimensions of sustainability namely: environmental dimension, social dimension, and economic dimension, there are 19 important strategic sustainability indicators.

3. Success indicators for strategic sustainability have high importance but low degree of certainty, which means serious attention is needed to ensure high sustainability is achieved.

4. Based on the ISM analysis method of the six elements studied, identified factors that influence the supply chain system of renewable energy development based on sustainable biomass of bamboo forest.

5. In designing a bamboo biomass feedstock system with sustainable community forestry empowerment, it is important to note what are the key factors of success, added value, and risks faced by actors involved in the supply chain system in order to maintain a sustainable condition.

6. In designing a sustainable supply chain business model for the development of bamboo biomass as renewable energy the main issue to note is that the generating capacity must be in line with demand for electricity by considering the demand growth carefully.

7. Renewable energy development is increasingly important, as the whole world is committed in 2015 to reduce carbon emissions, implement green economy, and reduce poverty that leads to sustainable development. Energy also serves as an essential factor in sustainable development and overcoming poverty.

B. Suggestions

1. The results of this study can be followed up among stakeholders to find development models for small island communities and remote villages.

2. Can be a reference and a concern of several International Institutions, this research has developed the PLTBM business model with bamboo biomass as raw material.

3. There is still room for future evaluation and improvement so that the concept of bamboo forest integration managed by PLTBM bamboo becomes the standard program for the development of rural electrification in Indonesia

4. Availability of managed bamboo forests, can replace firewood with bamboo slats, as a more rapid renewable alternative

5. People in rural areas can use electricity to increase household income with homebased industries.

\section{References}

Ashby, A., Leat, M., \& Hudson-Smith, M. (2012). Making connections: A review of supply chain management and sustainability literature. Supply Chain Management, 17(5), 497516. http://doi.org/10.1108/13598541211258573

Ballou, R. H. (2007). The evolution and future of logistics and supply chain management.

Bisgaard, T., Henriksen, K., \& Bjerre, M. (2012). Green Business Model Innovation Conceptualisation, Next Practice and Policy. 
Brundtland, G. (1987). Report of the World Commision on Environement and Development: Our Common Future. Oxford paperbacks (Vol. Report of). http://doi.org/10.2307/2621529

Gimenez, C., \& Tachizawa, E. M. (2012). Extending sustainability to suppliers: a systematic literature review. Supply Chain Management: An International Journal, 17(5), 531-543. http://doi.org/10.1108/13598541211258591

Gold, S. (2011). Bio-energy supply chains and stakeholders. Mitigation and Adaptation Strategies for Global Change, 16(4), 439-462. http://doi.org/10.1007/s11027-010-9272-8

Hall, J., \& Matos, S. (2010). Incorporating impoverished communities in sustainable supply chains. International Journal of Physical Distribution \& Logistics Management, 40(1/2), 124-147. http://doi.org/10.1108/09600031011020368

Hidayat, S., \& Marimin. (2014). Agent based modeling for investment and operational risk considerations in palm oil supply chain. International Journal of Supply Chain Management, 3(1), 34-40. Retrieved from https://www.scopus.com/inward/record.uri?eid=2-s2.084949799309\&partnerID=40\&md5=9ddf7c180f34ee9d b8ce0d8b9ee6fe51

Keith, D. W., \& Reinelt, S. (2009). Carbon Capture Retrofits and the Cost of Regulatory Uncertainty. Energy Journal, 28(4), 101-127.

Large, R. O., \& Gimenez Thomsen, C. (2011). Drivers of green supply management performance: Evidence from Germany. Journal of Purchasing and Supply Management, 17(3), 176-184. http://doi.org/10.1016/j.pursup.2011.04.006

Marimin, Darmawan, M. A., Machfud, Islam Fajar Putra, M. P., \& Wiguna, B. (2014). Value chain analysis for green productivity improvement in the natural rubber supply chain: A case study. Journal of Cleaner Production, 85, 201-211.

http://doi.org/10.1016/j.jclepro.2014.01.098

Schoenherr, T., Rao Tummala, V. M., \& Harrison, T. P. (2008). Assessing supply chain risks with the analytic hierarchy process: Providing decision support for the offshoring decision by a US manufacturing company. Journal of Purchasing and Supply Management, 14(2), 100-111. http://doi.org/10.1016/j.pursup.2008.01.008 Singh, A., \& Trivedi, A. (2016).

Sustainable green supply chain management: trends and current practices. Competitiveness Review Supply Chain Management: An International Journal, 26(3), 265-288. http://doi.org/10.1108/CR-05-2015-0034

Suharjito, \& Marimin. (2012). Risks balancing model of Agri-Supply chain using fuzzy risks utility regression. Journal of Theoretical and Applied Information Technology, 41(2), $134-144$.

Taylor, D. H. (2005). Value chain analysis: an approach to supply chain improvement in agrifood chains. International Journal of Physical Distribution \& Logistics Management, 35(10), 744-761.

http://doi.org/10.1108/09600030510634599 